\title{
DESIGN OF TURBINE RECUPERATOR FOR POWER SAVING AND REDUCTION OF EXHAUST GASES POLLUTION
}

El Samanoudy, M. A. ${ }^{(1)}$; Salama, S. A. ${ }^{(2)}$ and Kobessi, N. G.

1) Mechanical Power Engineering, Ain Shams University 2) Mechanical Power Engineering Specialized Studies Academy

\begin{abstract}
A $250 \mathrm{~W}$ turbo charger comprising of a radial turbine, a centrif ugal compressor with reverse flow combustor coupled to an electric generator to produce power is under development and testing stage at the laboratory. Also a swirling reverse flow recuperator has been designed and fabricated for integration with the turbo charger to recover waste heat coming out of the radial turbine and to improve thermal efficiency of the engine cycle. This paper covers the design, analysis, fabrication and testing of radial turbine and recuperator, with the design objective of higher effectiveness and lower pressure loss.The swirling recuperator with a cylinder surface has been designed and analyzed for stresses due to thermal and structural loads. A test rig set up with compressed air lines and space heaters (combustor) has been designed and fabricated. Simulated engine design conditions such as flow, pressure and temperatures were applied and thermal effectiveness and pressure drop across the model are evaluated, validating the theoretical predictions.A full scale swirling recuperator has also been fabricated for integration with the radial turbine.
\end{abstract}

Key words: Combustor -Turbocharger -Recuperator-Electric Genarator.

\section{INTRODUCTION}

A turbo charger is an emerging class of global power generation technology. They play an important role in evolving power generation both for standalone and for combined cycle application with fuel. Carrillo, R.A.M., 
(2010). Turbo charger consists of a generator, compressor, combustor, radial turbine and a swirling recuperator, all function together to generate power for small scale utilization. The swirling recuperator is an important component to achieve high thermal efficiency. C.F.McDonald., (2003).

The basic technology used in a turbo charger is derived from diesel engine technologies and automotive designs. Most turbo charger units are currently designed for continuous duty operation and are recuperated to obtain high thermal efficiency. They also have good fuel flexibility. The small radial turbines enable small energy users to generate their own electricity to secure power supply even at peak load periods also at power shortage. They also have advantages over the conventional power systems in compactness, silent running with low emission, multi fuel capabilities; vibration free with low maintenance and moderate to very high fuel utilization efficiency using waste heat recovery. Choi, H.-J., (2013).

The Oak Ridge National laboratories, USA have done a research program to evaluate the thermal efficiency dependence on material selection for various parametric variations of compressor pressure ratio and turbine inlet temperature (fig.1). E.Utriainen, B. Sunde’n., (2012). 


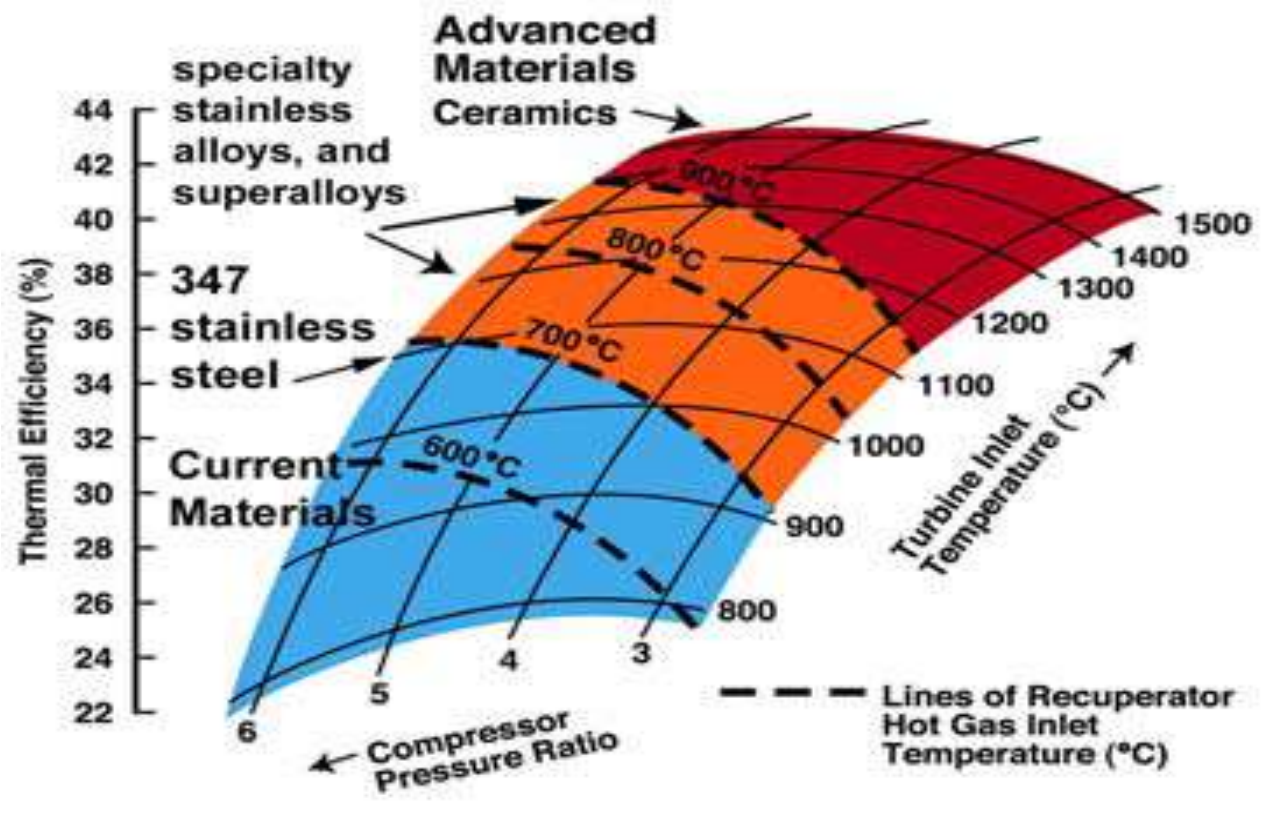

Fig. (1): The thermal efficiency dependence on material selection for various parametric variations of compressor pressure ratio and turbine inlet temperature.

A good recuperator requires minimum weight / volume, high thermal effectiveness, low pressure loss, high reliability and durability. Effectiveness is one of the key thermal performance parameter as indicated in fig (2), which shows the thermal efficiency variation. Fu, L., (2011).

To achieve the highest possible effectiveness, a counter flow recuperator must be used. 
J. Environ. Sci.

Institute of Environmental Studies and Research - Ain Shams University

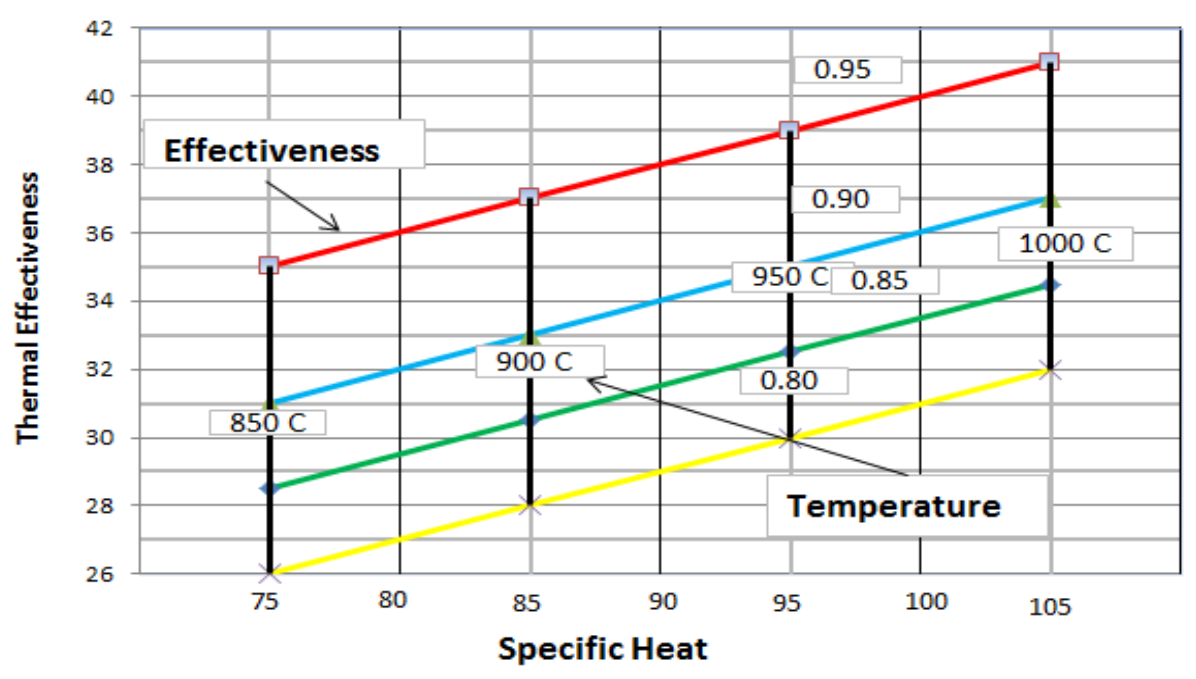

Fig. (2): The completely mapped mesh component

Major factors affecting the effectiveness are overall heat transfer coefficient and large heat transfer area; the same influenced by a number of factors $[6,7]$ like configuration of gas/air as sages, Reynolds number, Nusselt number and duct geometry. Another key performance parameter is the total relative pressure loss. Gunter, E.G.and Chen, W.J., (2005).

\section{PROBLEM DEFINITION}

The problem is increasing the pollution in the air and increasing the fuel consumption to generate electricity.

This paper covers the design, analysis, fabrication and testing of turbocharger, recuperator, and cyclone-scrubbers, with the design objective of higher effectiveness and lower pressure loss. Commercial package (ANSYS) was used for modeling, meshing and analysis geometry of recuperator. 
Simulated engine design conditions such as flow, pressure and temperatures were applied and thermal effectiveness and pressure drop across the model are evaluated, validating the theoretical predictions. Also design, fabrication and analysis cyclone-scrubbers.

\section{AIM OF THE RESEARCH}

The aim of this research is to design some devices that can help in controlling this pollution protecting the environmental quality and keep it with the required standards and save power by using heat recovery. In the process of the heat recovery, the exhausted heat can be re-used in many applications such as heating cold air, cold water, drying, coating, produce electricity and improving engine performance.

\section{METHODOLGY}

The research includes analytical and experimental analysis of the problem:

\section{The Analytical part of the present work includes:}

Design the exhaust gas heat exchanger (swirling recuperator cylinder) is used to recover heat energy by inter supply air through (swirling recuperator cylinder) to become hot air.

Design turbocharger besides (swirling recuperator cylinder) used heat recovery to rotate the shaft of turbine to generate electric current, rotation motor, blower or compressor.

Combined cyclone and scrubber with the modification of (CycloneScrubber) by fixed all moving part and addition helical rings to reduce pollutants from the waste and harmful to the environment associated with the various combustion processes. 
J. Environ. Sci.

Institute of Environmental Studies and Research - Ain Shams University

\section{The experimental work includes three parts:}

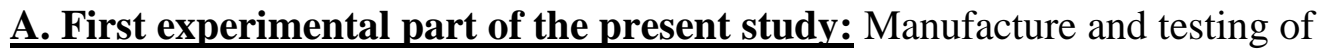
a heat exchanger (swirling Recuperator Cylinder) and providing the measurement devices to measure various temperatures and flow rates premade.

B. Second part of the experimental study: Manufacture and testing turbocharger fixed beside heat exchanger (Swirling Recuperator Cylinder) to rotate blower, generator and compressor.

C. Third part of the experimental study: Manufacture and testing the apparatus (Cyclone-Scrubber) is reduced the exhaust gas pollutants and produced a new environment friendly exhaust.

With the data provided, a complete 3D model of the recuperator is created. The basic methodology involved in creating the component is as follows:

Key points are created for the given dimensions or recuperator.

Lines are created by joining these key points.

Area and volumes are created by joining these lines and using Boolean operations.

\section{DESIGN OF RECUPERATOR}

1) DESIGN PROCEDURE: The objective of this design problem is to determine the recuperator effectiveness and pressure drop for both the air and gas sides for the specified conditions and the basic heat transfer and flow friction characteristics of the surface. The required Recuperator for the turbo charger is designed for the given specifications and the 
parameters are derived from a radial gas turbine cycle for optimum performance.

The following parameters are used for the thermal analysis:

1. Thermal conductivity of material $\quad \mathrm{k}=20.14 \mathrm{~W} / \mathrm{m} 2 \mathrm{~K}$

2. Number of swirling

$$
=9 \& 7
$$

3. Fin thickness

$$
=0.0005 \mathrm{~m}
$$

4. Air and gas side angle of passage are assumed as $60^{\circ}$ and $55^{\circ}$ respectively see fig (4).

5. Outlet temperature of gas side and air side are assumed so that it is easy to calculate the log mean temperature difference as the temperature is varying along the length.

$T_{\text {in }}=877 \mathrm{~K}$ and $T_{\text {out }}=543 \mathrm{~K}$

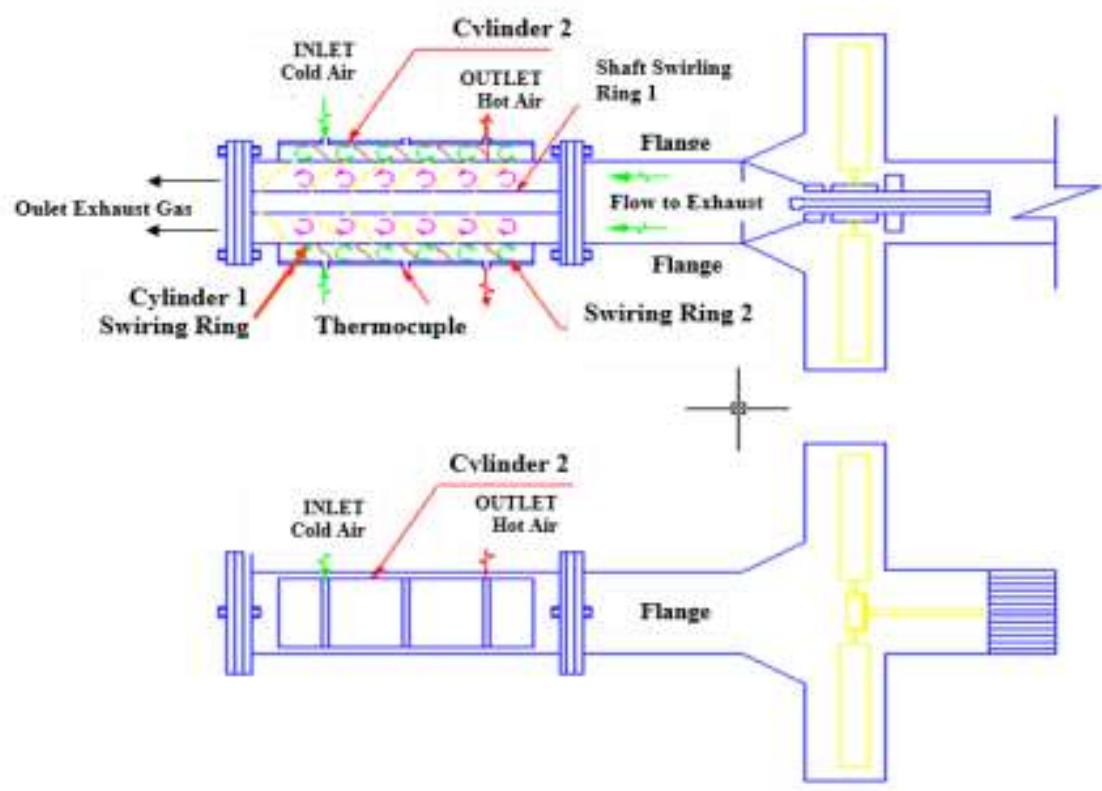

Fig (3) presents a working drawing of the design 


\section{2) CORE DIMENSIONS OF THE RECUPERATOR:}

Outer diameter of recuperator Do $=0.23 \mathrm{~m}$

Inner diameter of recuperator Di $=0.17 \mathrm{~m}$

Length of recuperator

$\mathrm{L}=0.80 \mathrm{~m}$

Air inlet ellipse major axis

$\mathrm{a} \quad=0.00825 \mathrm{~m}$

Air inlet ellipse minor axis

$\mathrm{b}=0.00330 \mathrm{~m}$

\begin{tabular}{|c|c|}
\hline Mass flow rate of air & $0.1279 \mathrm{~kg} / \mathrm{s}$ \\
\hline Air side inlet pressure $\left(\mathrm{p}_{\mathrm{ai}}\right)$ & $303.9 \mathrm{k} \mathrm{pa}_{\mathrm{pa}}$ \\
\hline Air side inlet temperature & $432 \mathrm{k}$ \\
\hline Mass flow rate of gas & $0.1289 \mathrm{~kg} / \mathrm{s}$ \\
\hline Gas side inlet pressure $\left(\mathrm{p}_{\mathrm{gi}}\right)$ & $100 \mathrm{k}_{\mathrm{pa}}$ \\
\hline Gas side inlet temperature & $955 \mathrm{k}$ \\
\hline
\end{tabular}

The steps in the design $\&$ analysis require the determination of the following factors:

1. Fluid properties.

2. Heat transfer and free flow areas.

3. Reynolds number.

4. Friction factor.

5. Pressure drop.

6. Overall coefficient of heat transfer.

3) RECUPERATOR (SWIRLING CYLINDER) MODELLING: For the present work the model is created in the ANSYS itself. In order to create a complete $3 \mathrm{D}$ model of the recuperator the data available are the $2 \mathrm{D}$ drawing and assembly drawing of the recuperator.

4) MATERIALS FOR RECUPERATOR: Steel 37 is used as a material for fabrication of swirling recuperator. Holmes et al., (2004). 
5) BOUNDARY CONDITIONS: More precisely, boundary conditions in a model must represent everything in the operating environment that is not explicitly modeled. Basically, loads are used to represent inputs to the system of interest. These can be in the form of the forces, moments, pressures, temperatures, or accelerations, whereas constraints on the other hand are typically used as reactions to the applied loads.Non-uniform temperature load, which forms the body load and the recuperator, is subjected to pressure load of 1 bar in the hot gas passage and 3bar in air passage.

(6) THERMAL ANALYSIS \& STRUCTURAL ANALYSIS: A thermal analysis calculates the temperature distribution and related thermal quantities in a system or component. Typical thermal quantities of interest are the temperature distributions; the amount of heat lost or gained thermal gradients and thermal fluxes. After applying the loads and boundary conditions, the model is solved as a steady state static model. Philip J. Maziasz et al., (2002). The results of the analysis are shown and discussed in the results and discussions section.

\section{RESULTS AND DISCUSSIONS}

Design calculations have been carried out for the swirling primary surface counter flow type recuperator for the given specifications and results of the analysis are highlighted below.

\begin{tabular}{|c|c|c|}
\hline Parameter & Air side & Gas side \\
\hline \hline Reynolds Number & 4235 & 4056 \\
\hline${\text { Pressure drop } \mathrm{k}_{\mathrm{pa}}}^{\mathrm{N}}$ & 2.871 & 3.148 \\
\hline Heat transfer coefficients w/m & 62.7 & 82.2 \\
\hline Heat transfer area $\mathrm{m}^{2}$ & 0.78 & 0.78 \\
\hline Effectiveness & \multicolumn{2}{|c|}{$70 \%$} \\
\hline
\end{tabular}


The pressure drop on the air side was $1.8 \%$ and pressure drop on the gas side was $6 \%$ so total pressure drop in recuperator was $7.8 \%$ which was well within the acceptable range of $8 \%$. The overall heat transfer coefficient is one of major parameters, which influence the effectiveness.

The heat transfer coefficients obtained for both air and gas sides were low and so this resulted in an increase in effectiveness. The amount of heat transferred and effectiveness also depends on area of heat transfer. From the design results, the obtained values of area of heat transfer are high i.e. 0.78 $\mathrm{m} 2$ so this also contributes to increase of effectiveness. The effectiveness of the recuperator was about $70 \%$, the reason behind this high effectiveness is the high heat transfer coefficients, high heat transfer areas and high compactness of the recuperator. Compactness is the ratio of heat transfer surface area to enclosed volume.

\section{RESULTS OF EXPERIMENTS}

The measured performance data along with derived values of effectiveness in percentage and percentage of pressure loss in both air and gas side of model with the percentage variation of design mass flow parameter are listed below. Temperatures were measured to an accuracy of 1 degree centigrade and mass flow rates are set.

Temperatures were measured to an accuracy of 1 degree centigrade and mass flow rates are set to an accuracy of $+/-3 \%$ tolerance see table (1). 
Table (1): the variation of effectiveness with gas input mass flow parameter

\begin{tabular}{|c|c|c|c|c|c|c|c|c|c|}
\hline $\begin{array}{c}\% \\
\text { design } \\
\text { mass } \\
\text { flow }\end{array}$ & $\begin{array}{c}\% \text { air } \\
\text { pressure } \\
\text { loss }\end{array}$ & $\begin{array}{c}\text { Model } \\
\text { air } \\
\text { inlet } \\
\text { temp } \\
\text { OC }\end{array}$ & $\begin{array}{c}\text { Model } \\
\text { air } \\
\text { outlet } \\
\text { temp } \\
\text { 0C }\end{array}$ & \multicolumn{2}{|c|}{$\begin{array}{l}\mathrm{m} / \mathrm{Tm} / \mathrm{pmx10-7} \\
(\mathrm{kg} / \mathrm{sec} / \mathrm{k} / \mathrm{N} / \mathrm{m} 2)\end{array}$} & $\begin{array}{c}\% \text { gas } \\
\text { pressure } \\
\text { loss }\end{array}$ & $\begin{array}{c}\text { Model } \\
\text { gas } \\
\text { inlet } \\
\text { temp } \\
\text { OC }\end{array}$ & $\begin{array}{c}\text { Model } \\
\text { gas } \\
\text { outlet } \\
\text { temp } \\
\text { 0C }\end{array}$ & Effectiveness\% \\
\hline 50 & 1.83 & 30.4 & 44.1 & 2.1 & 4.97 & 0.23 & 590 & 481 & 37.55 \\
\hline 60 & 2.42 & 30.37 & 43.0 & 2.54 & 6.13 & 0.29 & 588.5 & 490.5 & 34.85 \\
\hline 70 & 3.50 & 30.35 & 42.6 & 3.03 & 7.25 & 0.39 & 588.5 & 494.5 & 33.70 \\
\hline 80 & 4.87 & 30.33 & 42.15 & 3.48 & 8.47 & 0.50 & 588.5 & 497.5 & 32.50 \\
\hline 90 & 5.72 & 30.25 & 42.2 & 3.8 & 9.38 & 0.60 & 589 & 499 & 32.69 \\
\hline 100 & 6.90 & 30.2 & 41.4 & 4.06 & 10.40 & 0.74 & 586 & 505 & 30.85 \\
\hline 110 & 8.56 & 304 & 423.5 & 4.72 & 11.19 & 0.82 & 669 & 588.5 & 32.74 \\
\hline
\end{tabular}

It is observed +/- 3\% variation in effectiveness which is obvious with variation in setting mass flow mentioned above. An average effectiveness obtained from experiments is approximately $70 \%$ coinciding with the design value see fig (4).

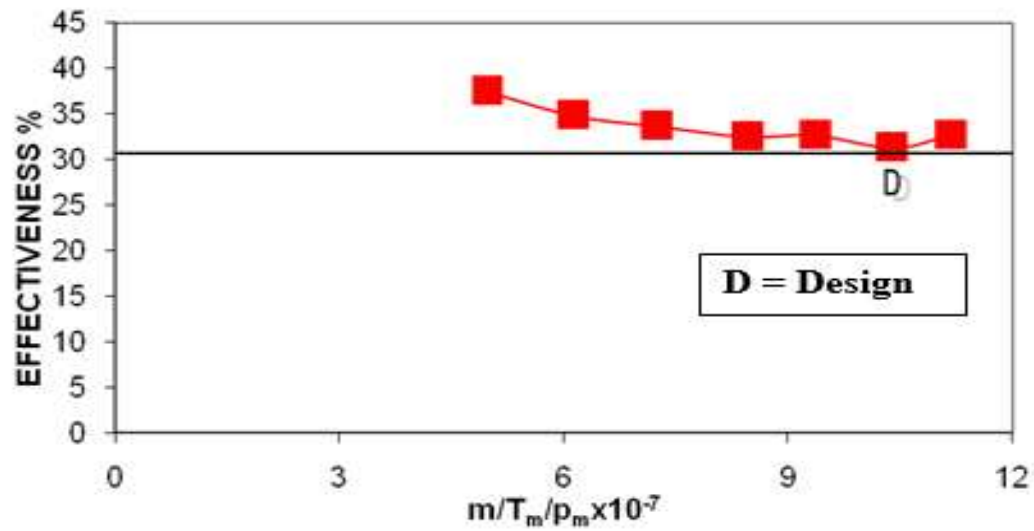

Fig (4) Effectiveness with input mass flow parameter (gas)

Shows variation of percentage pressure loss with gas input mass flow parameter for both air and gas sides. Pressure loss on the air side varies within $1 \%$ and the pressure loss in gas side is little higher. This is due to gas entering 
into the model through the swirling cylinder passage which is not true in actual prototype giving additional loss. Fig (5) \& (6)

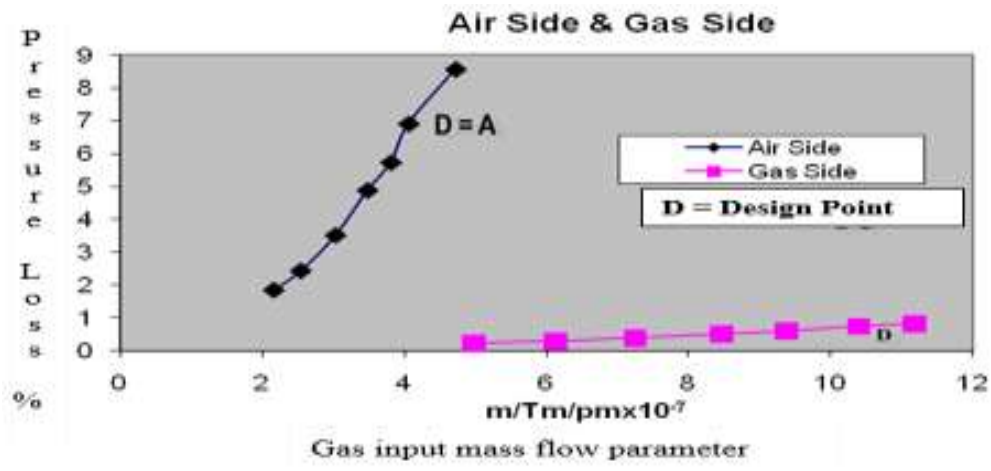

Fig (5) Pressure loss with gas input mass flow parameter

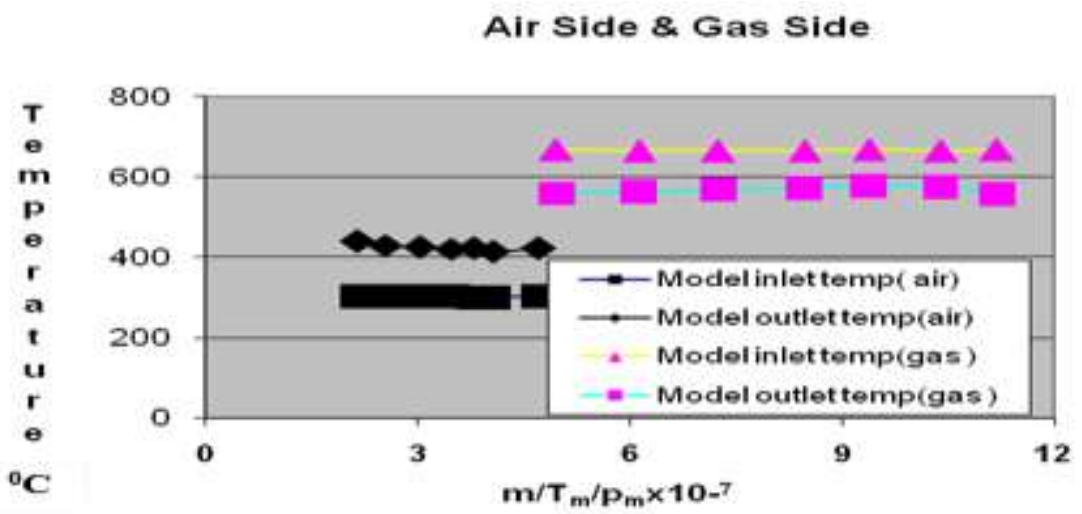

Fig (6) Variation of temperature with input mass flow parameter

Show the variation of temperatures at both inlet and outlet of model for air as well as gas side with mass flow parameter. The results clearly indicate scope for space improvement in effectiveness by increasing the surface area and turbulence levels for future studies. 


\section{TURBOCHARGING}

1) Introduction: Turbochargers are a class of turbo machinery intended to increase the power of internal combustion engines. This is accomplished by increasing the pressure of intake air, allowing more fuel to be combusted.

In the late 19th century, Rudolf Diesel and Gottlieb Daimler experimented with pre-compressing air to increase the power output and fuel efficiency. The first exhaust gas turbocharger was completed in 1925 by the Swiss engineer Alfred Buchi who introduced a prototype to increase the power of a diesel engine by a reported $40 \%$. The idea of turbo charging at that time was not widely accepted. However, in the last few decades, it has become essential in almost all diesel engines with the exception of very small diesel engines. Utriainen, E., (2001).

2) Turbocharged Engines: Turbocharged engines made a comeback during the oil shortage in the early 70's due to their inherent increase in fuel efficiency. The advances in rotor dynamic analysis using up-to date computation technology have made the dynamics of a turbocharger's rotor-bearing system a rich area for investigation. Vendors are now looking for more dynamically stable turbochargers to benefit business and increase customer satisfaction. More contributions are needed to have optimum design stability, while assuring continued low cost production. They also require a high level of reliability and efficiency in order to be cost-effective. 
There are several ways to reduce the price of turbochargers; the easiest way is to keep the design as simple as possible.A common design assembly in an automotive turbocharger consists of a simple inboard bearing mounting arrangement with a radial outflow compressor and a radial inflow turbine on a single shaft see fig (7).

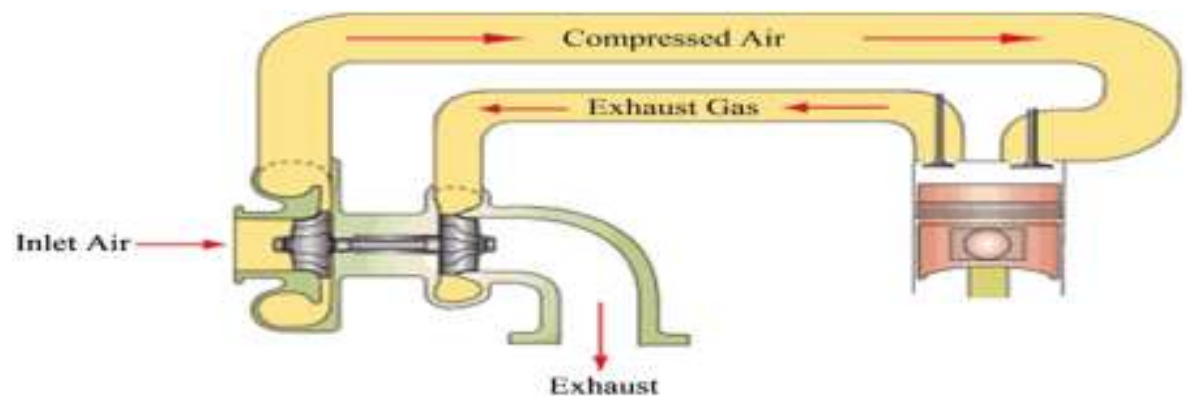

Fig (7): typical turbocharger space with compressor wheel and turbine

Thermodynamic processes consist of: Housing-Compressor-RecuperatorCombustion chamber -Turbine - Exhaust-gas heat-exchanger

\section{$\underline{X-\text { Rapid Design and Flow Simulations for Turbocharger Components: }}$}

(1) Simulated Cases: Three Impellers, One Volute

1. Impeller without Tip Clearance

2. Impeller with $0.2 \mathrm{~mm}$ Tip clearance

3. Impeller with $0.4 \mathrm{~mm}$ Tip clearance 

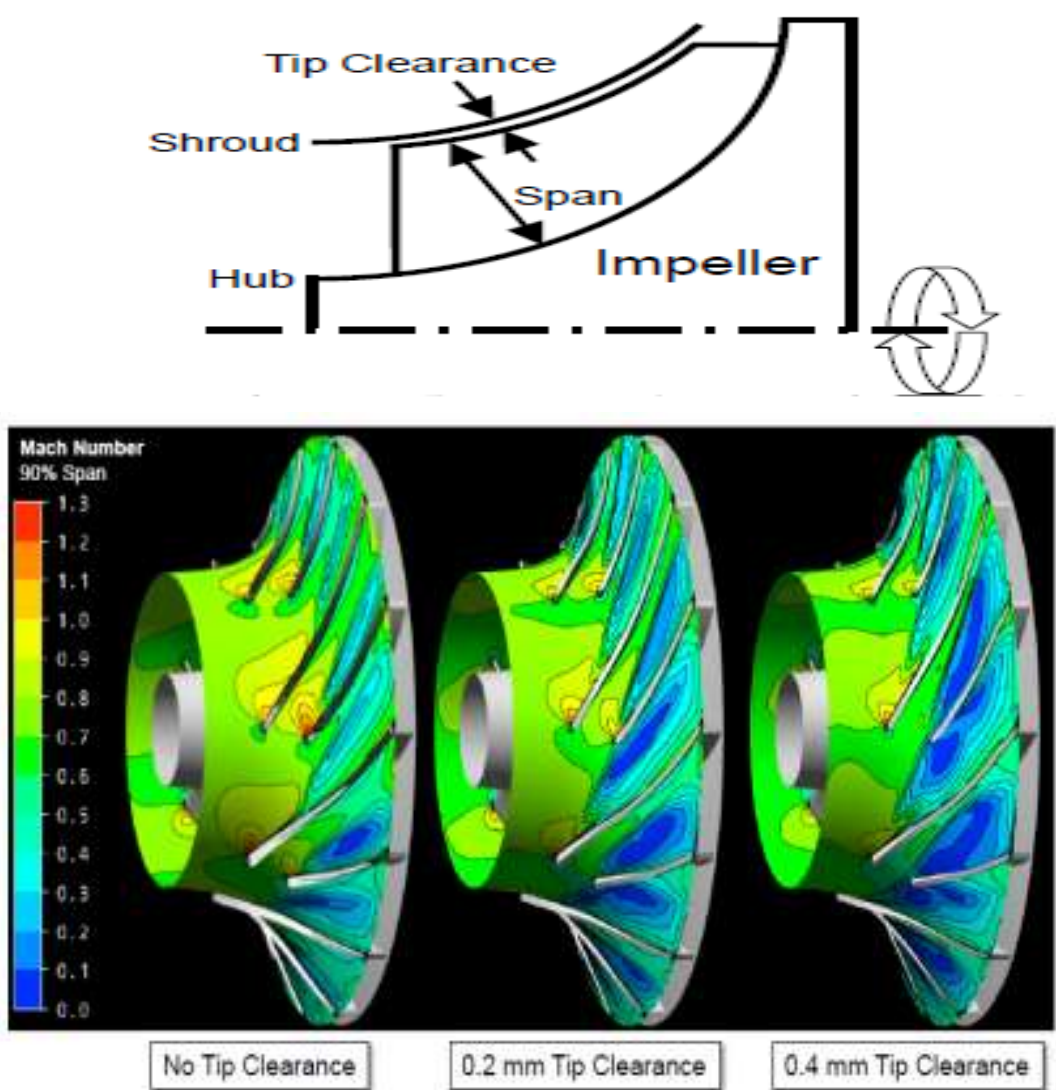

Fig. (8): Differences tip clearance in Mach number Distribution

\section{(2) Performance:}

\section{1-Efficiency\& mass flow rate}

- No tip clearance

$\circ \mathrm{mm}$ tip clearance

- $0.4 \mathrm{~mm}$ tip clearance 
J. Environ. Sci.

Institute of Environmental Studies and Research - Ain Shams University

Table (2): Relation between isentropic efficiency \& mass flow rate at different tip clearance.

\begin{tabular}{|c|c|c|c|c|c|}
\hline \multicolumn{7}{|c|}{ No tip clearance } \\
\hline \hline Isentropic Efficiency \% & 0.78 & 0.80 & 0.63 & 0.47 & 0.25 \\
\hline Mass flow rate kg/s & 0.25 & 0.32 & 0.41 & 0.43 & 0.44 \\
\hline \multicolumn{6}{|c|}{ } \\
\hline Isentropic Efficiency \% clearance \\
\hline Mass flow rate kg/s & 0.78 & 76 & 0.61 & 0.45 & 0.24 \\
\hline $\mathbf{0 . 4 m m}$ tip clearance \\
\hline Isentropic Efficiency \% & 0.27 & 0.31 & 0.38 & 0.41 & 0.42 \\
\hline \hline
\end{tabular}

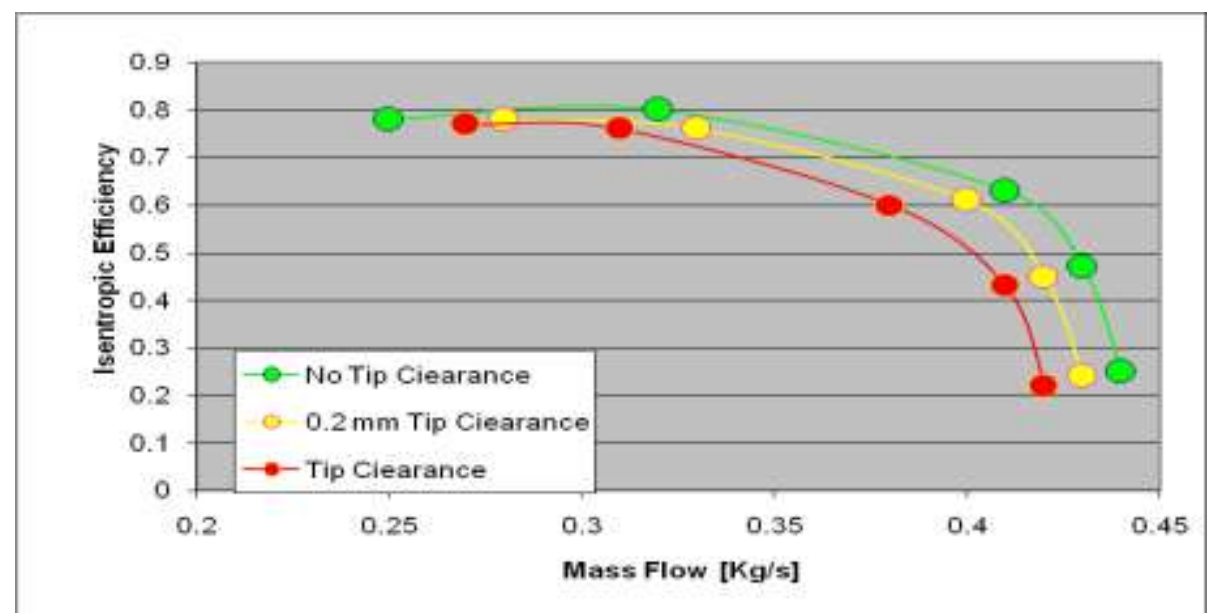

Fig. (9): Relation between isentropic efficiency \& mass flow rateat different tipclearance 


\section{2- Total pressure ratio \& mass flow rate:}

Table (3): Relation between total pressure ratio \& mass flow rate at different tip clearance

\begin{tabular}{||c|c|c|c|c|c|c|}
\hline \multicolumn{10}{|c|}{ No tip clearance } \\
\hline total Pressure ratio & 2.2 & 2.1 & 2 & 1.75 & 1.38 & 1.20 \\
\hline Mass flow rate $(\mathrm{kg} / \mathrm{s})$ & 0.26 & 0.32 & 0.36 & 0.4 & 0.43 & 0.44 \\
\hline \multicolumn{8}{|c|}{ 0.2mmtip clearance } \\
\hline Total pressure ratio & 2.13 & 1.97 & 1.60 & - & 1.39 & 1.20 \\
\hline Mass flow rate $(\mathrm{kg} / \mathrm{s})$ & 0.28 & 0.33 & 0.38 & - & 0.41 & 0.43 \\
\hline \multicolumn{8}{|c|}{ 0.4mm tip clearance } \\
\hline Total pressure ratio & 2.07 & 1.96 & 1.60 & 1.38 & 1.19 & - \\
\hline Mass flow rate $(\mathrm{kg} / \mathrm{s})$ & 0.27 & 0.31 & 0.37 & 0.40 & 0.42 & - \\
\hline
\end{tabular}

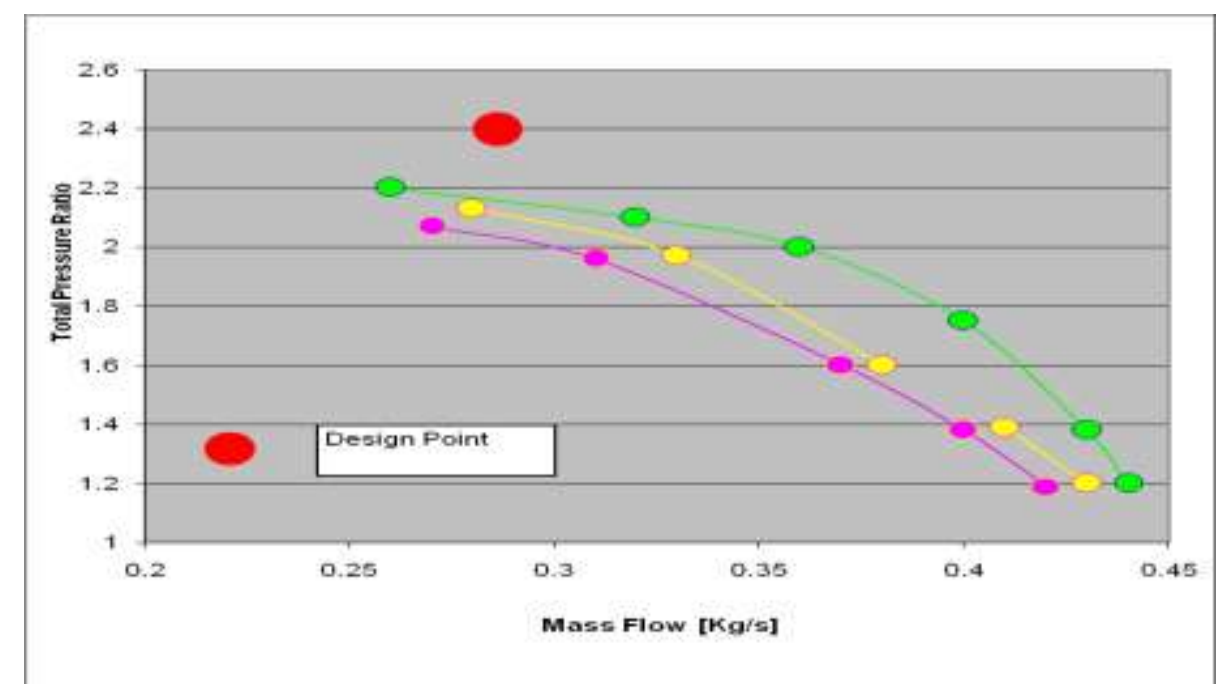

Fig. (9): relation between total pressure ratio \& mass flow rate 
J. Environ. Sci.

Institute of Environmental Studies and Research - Ain Shams University

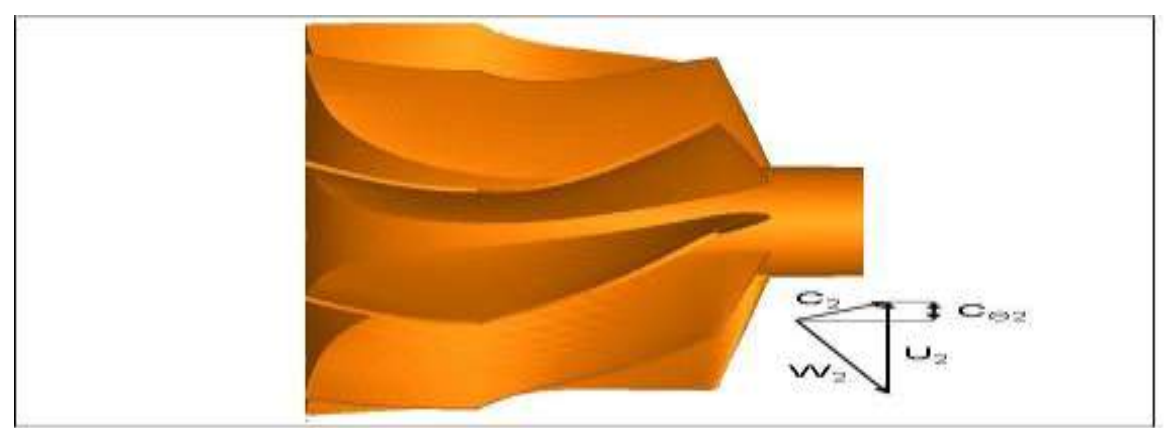

Fig. (10): Rotor inlet and outlet velocity triangles.

Another way to increase the efficiency of the turbine is to use back swept blades, with an inlet tip diameter of $90 \mathrm{~mm}$.

They studied three different back sweep blade angles; 0, 15, and 30. At design condition, the efficiency was almost equally, while at off-design conditions, the efficiency was improved by $2 \%$ for the 30 back sweep angle blade due to a strongly reduced tip vortex at the leading edge.

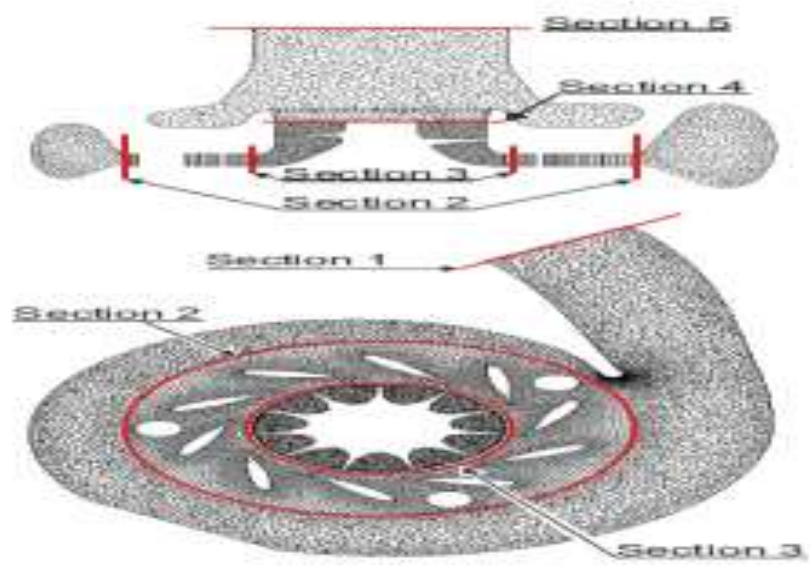

Fig. (11): Schematic representation of the turbine geometry and 3D computational mesh. 
Table (4): Turbocharger Specifications

\begin{tabular}{|c|c|}
\hline Engine capacity (L) & Up to 7 \\
\hline Output range (hp) & 100 to 310 \\
\hline Air flow(max) & $0.46 \mathrm{~kg} / \mathrm{s}$ \\
\hline Length (mm) & 250 \\
\hline Width (mm) & 240 \\
\hline Height (mm) & 220 \\
\hline Mass ( kg) & 17 \\
\hline
\end{tabular}

Table (5): shows Thermal source main data.

\begin{tabular}{|c|c|}
\hline Parameter & Burner \\
\hline Mass flow rate $(\mathrm{kg} / \mathrm{s})$ & 0.15 \\
\hline Exhausts temperature $(\mathrm{K})$ & 1123 \\
\hline Pressure $(\mathrm{kPa})$ & 290 \\
\hline $\begin{array}{c}\text { Average composition }(\text { per cent by } \\
\text { volume) }\end{array}$ & $\mathrm{CO}=0.041 ; \mathrm{CO} 2=2.74 ; \mathrm{O} 2=$ \\
$17.14, \mathrm{CxHy} \leq 0.03$
\end{tabular}

In order to find out the feasibility of running, a DC dynamo connected by

the turbo charger. The engine was allowed to run at different speeds the output of the generator was also noted.

Table (6): Relation between pressure\& mass flow rate and power

\begin{tabular}{|c|c|c|c|}
\hline Pressure(KPa) & Mass flow rate(kg/s) & Power (W) & $\begin{array}{c}\text { Exhausts } \\
\text { temperature(K) }\end{array}$ \\
\hline $25=0.25$ bar & 0.0183 & 442 & \multirow{12}{*}{1123} \\
\hline $50=0.5 \mathrm{bar}$ & 0.0367 & 884 & \\
\hline $100=1 \mathrm{bar}$ & 0.0692 & 6394 & \\
\hline $120=1.2$ bar & 0,0789 & 8221 & \\
\hline $140=1.4$ bar & 0.0877 & 9925 & \\
\hline $160=1.6$ bar & 0.0957 & 11504 & \\
\hline $180=1.8$ bar & 0.102 & 13466 & \\
\hline $210=2.1 \mathrm{bar}$ & 0.112 & 15590 & \\
\hline $230=2.3 \mathrm{bar}$ & 0.122 & 16981 & \\
\hline $250=2.5$ bar & 0.133 & 18512 & \\
\hline $270=2.7 \mathrm{bar}$ & 0.144 & 20043 & \\
\hline $290=2.9 \mathrm{bar}$ & 0.154 & 21435 & \\
\hline
\end{tabular}


J. Environ. Sci.

Institute of Environmental Studies and Research - Ain Shams University

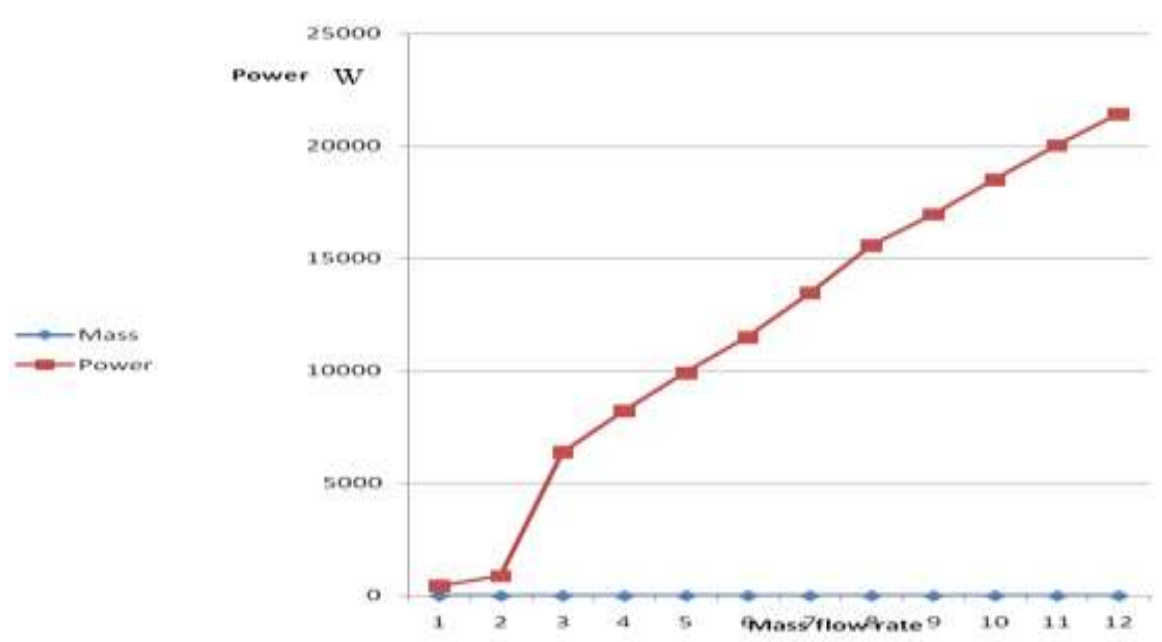

Fig (12) Relation between power \& mass flow rate

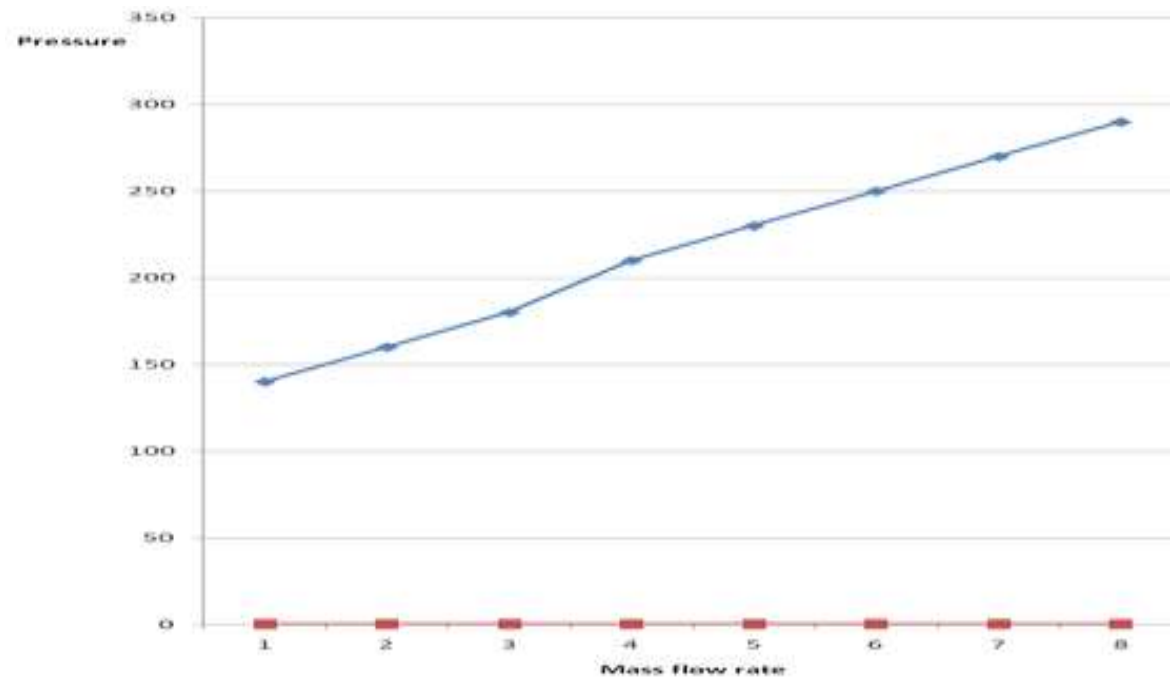

Fig. (13): Relation between pressure (Kpa) \& mass flow rate $(\mathrm{kg} / \mathrm{s})$

Power produced by the electrical machine

Power $(\mathrm{P})=$ Voltage $\mathrm{x}$ Current

(P) $=9 \mathrm{~V} \times 0.48 \mathrm{~A}=4.3 \mathrm{~W}$ atts 
Table (7): Relation between speed\& voltage\&power \& ampere

\begin{tabular}{|c|c|c|c|c|c|c|c|c|c|c|c|c|c|}
\hline $\begin{array}{c}\text { Engine } \\
\text { Speed in } \\
\text { KRPM }\end{array}$ & $\mathbf{2 . 4}$ & $\mathbf{6}$ & $\mathbf{9 . 6}$ & $\mathbf{1 4 . 4}$ & $\mathbf{2 4}$ & $\mathbf{3 8 . 4}$ & $\mathbf{5 6 . 4}$ & $\mathbf{7 0 . 8}$ & $\mathbf{8 5 . 2}$ & $\mathbf{9 9 . 6}$ & $\mathbf{1 1 5}$ & $\mathbf{1 3 0}$ & $\mathbf{1 4 0}$ \\
\hline \hline $\begin{array}{c}\text { Output } \\
\text { voltage of } \\
\text { the } \\
\text { Alternator }\end{array}$ & 9 & 22.5 & 36 & 54 & 90 & 144 & 212 & 266 & 320 & 374 & 432 & 488 & 526 \\
\hline Power (w) & 4.3 & 10.8 & 17 & 10.8 & 43 & 69 & 101 & 128 & 154 & 180 & 207 & 234 & 252 \\
\hline Ampere & \multicolumn{10}{|c|}{0.48} \\
\hline
\end{tabular}

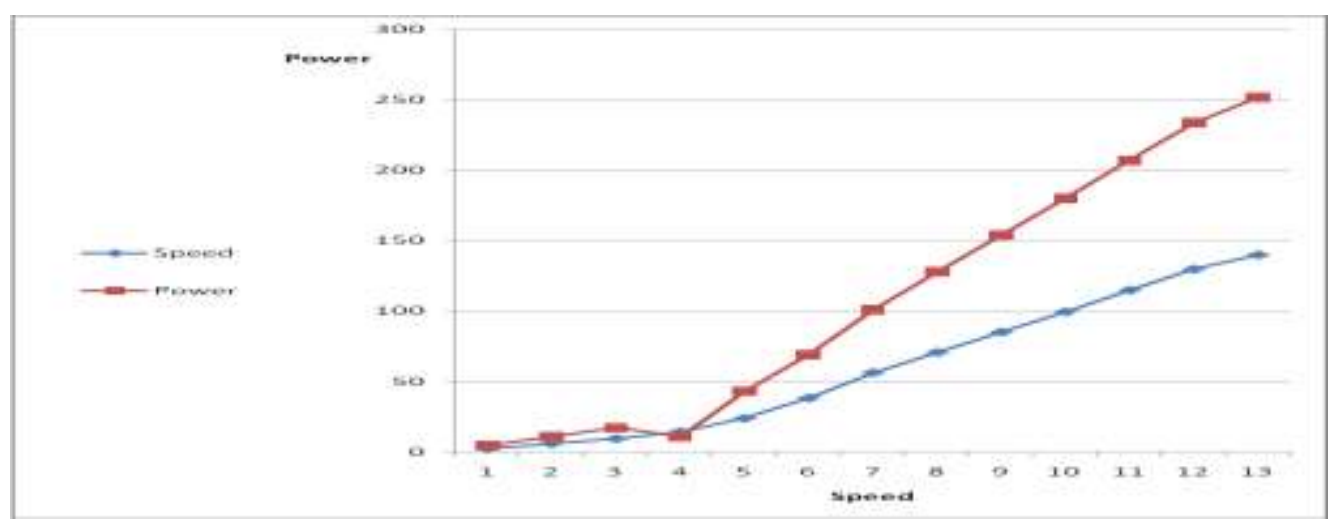

Fig. (14): Relation between rpm \&power (w)

\section{CONCLUSIONS}

- The design of a recuperator for a $250 \mathrm{~W}$ small turbine has been carried out for given operating conditions.

- Design calculations were also carried out for plain fin geometry for thermal and structural analysis.

- To begin with an annular primary surface recuperator was considered for the design.

- The results obtained from the design are, total pressure drop of recuperator was within allowable limit but effectiveness of the system was only $35 \%$. 
- Thermal and structural analysis is carried for an annular recuperator; the temperature distribution obtained from thermal analysis was applied as body load in the structural analysis.

- In average effectiveness obtained from experiments is approximately $70 \%$ coinciding with the design value.

- The variation of percentage pressure loss with gas input mass flow parameter for both air and gas sides.

- Pressure loss on the air side varies within $1 \%$ and the pressure loss in gas side is little higher. This is due to gas entering into the model through the swirling cylinder passage which is not true in actual prototype giving additional loss.

- The variation of temperatures at both inlet and outlet of model for air as well as gas side with mass flow parameter. The results clearly indicate scope for improvement in effectiveness by increasing the surface area and turbulence levels for future studies.

\section{From turbine we notice that:}

- From no tip clearance we notice that the efficient increase about $80 \%$, but from both $0.2 \mathrm{~mm}$ tip clearance \& $0.4 \mathrm{~mm}$ tip clearance is lower than $80 \%$.

- To increase the efficiency of the turbine is to use back swept blades, with an inlet tip diameter of $90 \mathrm{~mm}$.

- The design point between total pressure ratio and mass flow rate $=2.4 / 0.28$ and 1.3/0.22.

- One the speed increase the voltage is increase and the power is increase. 


\section{REFERENCES}

Carrillo, R.A.M., (2010): Radial Inflow Turbine One And Tri-Dimensional Design Analysis Of $600 \mathrm{Kw}$ Simple Cycle Gas Turbine Engine, Journal of Proceedings of The Asme Turbo Expo, Vol 5, New York, pp 477-486.

C.F.McDonald., (2003): Recuperator considerations for future higher efficiency microturbines, Journal of Applied Thermal Engineering, Vol. 23, pp 1463-1487.

Choi, H.-J., (2013): CFD validation of performance improvement of a 500 kW Francis turbine, Journal of Renewable Energy, Vol 54(0): pp. 111-123.

E.Utriainen, B. Sunde'n., (2012): Evaluation of the Cross Corrugated and Some Other Candidate Heat Transfer Surfaces for Microturbine Recuperators ASME, Journal of Engineering for Gas Turbines Power, and Vol. 124, pp 550-560.

Fu, L., (2011): Integrated Optimization Design for a Radial Turbine Wheel of a $100 \mathrm{~kW}$-Class Microturbine, Journal of Engineering for Gas Turbines and Power, Vol 134(1): pp 012301-012301.

Gunter, E.G.and Chen, W.J., (2005): Dynamic Analysis of a Turbocharger in Floating Bushing Bearings, Proc.3rd International Symposium on Stability Control of Rotating Machinery, Cleveland, OH.

Holmes, R.Brennan, M.J.and Gottrand, B., (2004): Vibration of an Automotive.Turbocharger-A Case Study, Proc. 8th International Conference onVibrations in Rotating Machinery, Swansea, UK, pp.445-450.

Philip J. Maziasz, Bruce A. Pint, Robert W. Swindeman, Karren L. More and Edgar Lara-Curzio, (2002): Advanced alloys for high temperature recuperators, March DER Peer Review, Oak Ridge national Laboratory.

Utriainen, E., (2001): Investigation of some heat transfer surfaces for gas turbine recuperators, Ph.D thesis, Lund University, Sweden. 
J. Environ. Sci.

Institute of Environmental Studies and Research - Ain Shams University

\section{INDEX}

CFD Computational Fluid Dynamics

HSG High Speed Generator

FEA Finite Element Analysis

ISA International Standard Atmosphere

RIT Royal institute of technology

Symbols are listed in alphabetical order. Values are listed for symbols

denoting constants:

\begin{tabular}{|c|c|c|}
\hline $\begin{array}{c}\text { Symbol (According } \\
\text { to SI system) }\end{array}$ & Meaning & Units \\
\hline \hline $\mathrm{b}$ & Static pressure & $\mathrm{Pa}$ \\
\hline $\mathrm{C}$ & Chord & $\mathrm{mm}$ \\
\hline $\mathrm{H}$ & Total specific enthalpy change & $\mathrm{j} / \mathrm{kg}$ \\
\hline $\mathrm{U}$ & Internal energy & $\mathrm{j}$ \\
\hline $\mathrm{V}$ & Absolute velocity & $\mathrm{m} 2 / \mathrm{s}$ \\
\hline $\mathrm{U}$ & Tangential velocity & $\mathrm{m} / \mathrm{s}$ \\
\hline $\mathrm{W}$ & Relative velocity & $\mathrm{m} / \mathrm{s}$ \\
\hline $\mathrm{H}$ & Specific enthalpy; specific loss & $\mathrm{j} / \mathrm{kg}$ \\
\hline $\mathrm{N}$ & Number of blades & $\mathrm{radial}$ \\
\hline $\mathrm{R}$ & Radius & $\mathrm{mm}$ \\
\hline $\mathrm{S}$ & Blade pitch, gap between Blade and housing & $\mathrm{mm}$ \\
\hline $\mathrm{B}$ & Blade height & $\mathrm{mm}$ \\
\hline $\mathrm{L}$ & Channel length & $\mathrm{mm}$ \\
\hline $\mathrm{W}$ & Width & $\mathrm{mm}$ \\
\hline $\mathrm{m}$. & Mass flow rate & $\mathrm{Kg} / \mathrm{s}$ \\
\hline$\mu$ & Absolute Viscosity & $\mathrm{m} 2 / \mathrm{s}$ \\
\hline$\Omega$ & Angular velocity & $\mathrm{s}-1$ \\
\hline F & Reynolds number & - \\
\hline Re & Radial of velocity & - \\
\hline R & Diameter & $\mathrm{r} / \mathrm{s}$ \\
\hline$D$ & Impeller & $\mathrm{mm}$ \\
\hline $\mathrm{I}$ & Friction factor, equation of state & $\mathrm{mm}$ \\
\hline EE AA & Egyptian Environment Affairs Agency & - \\
\hline IGSR & Information Gas System Research & - \\
\hline EIMP & Environmental Information and & - \\
\hline \multicolumn{2}{|c|}{ Monitoring Project } \\
\hline
\end{tabular}


El Samanoudy, et al

\begin{tabular}{|c|c|c|c|c|}
\hline & $\begin{array}{c}\text { Fundamental } \\
\text { parameters }\end{array}$ & $\begin{array}{c}\text { Non dimensional } \\
\text { parameters }\end{array}$ & $\begin{array}{c}\text { Quasi-non } \\
\text { dimensional } \\
\text { parameters }\end{array}$ & $\begin{array}{c}\text { Referred } \\
\text { parameters }\end{array}$ \\
\hline $\begin{array}{c}\text { Mass } \\
\text { flow }\end{array}$ & $\dot{m}$ & $\frac{m \sqrt{R T_{0} / \gamma}}{p_{0} D^{2}}$ & $\frac{m \sqrt{T_{0}}}{p_{0}}$ & $\frac{m \sqrt{T_{0} / T_{r e f}}}{P_{0} / P_{r e f}}$ \\
\hline $\begin{array}{c}\text { Pressure } \\
\text { ratio }\end{array}$ & $P R$ & $P R$ & $P R$ & $P R$ \\
\hline $\begin{array}{c}\text { Rot. } \\
\text { speed }\end{array}$ & $\mathrm{N}$ & $\frac{N \cdot D}{\sqrt{\gamma-R \cdot T_{0}}}$ & $\frac{N}{\sqrt{T_{0}}}$ & $\frac{N}{\sqrt{T_{0} / T_{r<}}}$ \\
\hline Efficiency & $\eta$ & $\eta$ & $\eta$ & $\eta$ \\
\hline
\end{tabular}

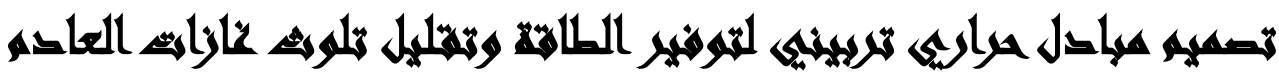

\section{[०]}

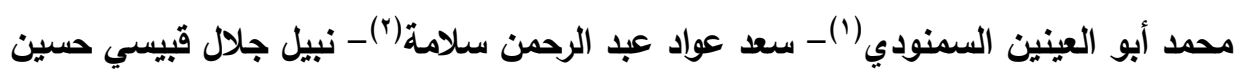

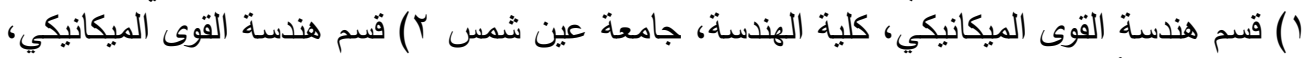

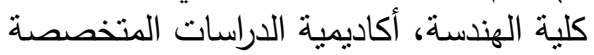

\section{المستخليس}

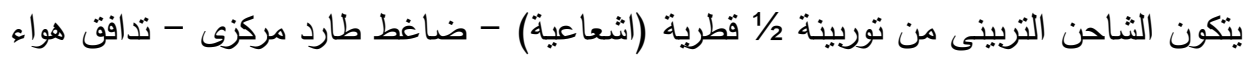

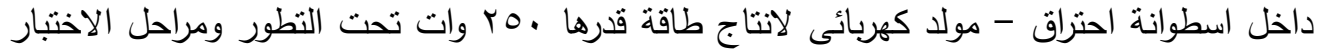

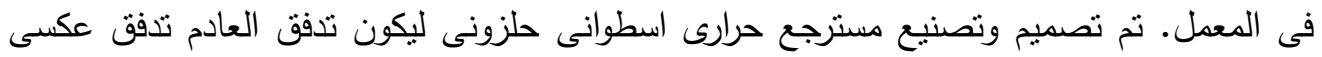

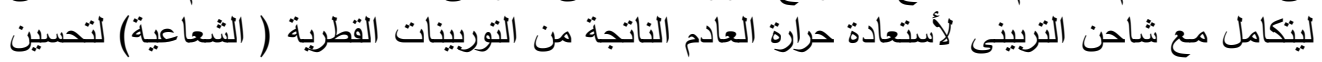

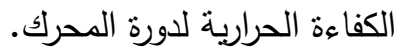

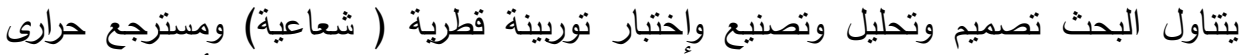

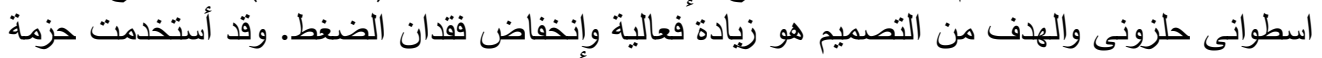

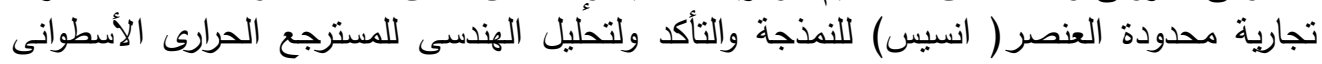

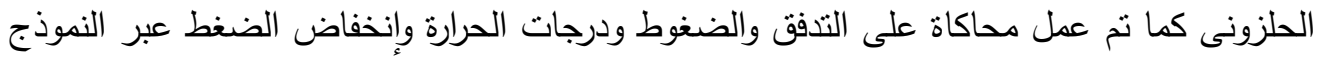
والتحقق من صحة النتبؤات النظرية. الكلمات المفتاحية: شاحن تربينى - مسترجع حرارى اسطوانى حلزونى - مولا كهربائى - محرك أو ولاعة احتراق 